\title{
Corynespora cassiicola f. sp. schinii, a Potential Biocontrol Agent for the Weed Schinus terebinthifolius in the United States
}

Davi Mesquita de Macedo and Olinto Liparini Pereira, Departamento de Fitopatologia, Universidade Federal de Viçosa, Viçosa, Minas Gerais, 36570-000, Brazil; Gregory Sherman Wheeler, United States Department of Agriculture-Agricultural Research Service, Invasive Plant Research Laboratory, Fort Lauderdale, FL 33314; and Robert Weingart Barreto, Departamento de Fitopatologia, Universidade Federal de Viçosa, Brazil

\begin{abstract}
Mesquita de Macedo, D., Pereira, O. L., Wheeler, G. S., and Barreto, R. W. 2013. Corynespora cassiicola f. sp. schinii, a potential biocontrol agent for the weed Schinus terebinthifolius in the United States. Plant Dis. 97:496-500.

Schinus terebinthifolius (Anacardiaceae), Brazilian peppertree (BP), is a major environmental weed in many tropical and subtropical areas of the globe, including Florida, Hawai'i, and Australia. This plant has been the target of a classical biocontrol project in the United States involving pathogens collected in Brazil for several years. A fungus was found in the Brazilian state of Espírito Santo causing leaf spots and severe foliage blight on BP. Examination of the morphology and internal transcribed spacer sequence analysis confirmed that the fungus is a strain of Corynespora cassiicola. Preliminary host-range tests involv-

ing 24 species, including 11 species in the family Anacardiaceae, were conducted with the fungus, and specificity toward BP was confirmed Plants of Brazilian pepper tree from populations in Florida and Hawai' $i$ included in the tests became severely diseased. Therefore, the recognition of a new forma specialis-Corynespora cassiicola f. sp. schiniiis proposed. The specificity of this forma specialis and the severity of the disease it caused in the field and under controlled conditions indicate that it has the potential for use as a biocontrol agent for BP in areas where it is an exotic invasive species.
\end{abstract}

Schinus terebinthifolius Radd., commonly known in the United States as Brazilian peppertree (BP) and Christmas berry, is a shrub or small tree of the family Anacardiaceae. It is native to Brazil (where it is known as aroeira), Argentina, and Paraguay. In Brazil, it is distributed from the northeast states to the extreme south in the state of Rio Grande do Sul (18). Many uses of BP are listed in the literature, including for medicinal purposes $(4,21)$, in construction, for energy (firewood and charcoal), and for restoration of degraded areas (18).

BP was introduced in the United States (Florida) in the late 1800 s as an ornamental (37). Since then, it has become one of the worst invasive plants of natural ecosystems, threatening native plant biodiversity in California, Florida, and Hawai'i $(9,11,29)$. Recently, it has also been listed among the 20 worst invasive plants in Australia (12). Searches for natural enemies of BP have been performed in Brazil, Argentina, and Paraguay since the 1950s (16), as part of the effort to mitigate the invasions of BP in Hawai' $i$. These were conducted by entomologists and led to the introduction of three insects in Hawai'i: two Lepidoptera, Episimus unguiculus Clarke (= E. utilis Zimmerman) (in 1954) and Crasimorpha infuscata Hodges (in 1961), and one Coleoptera, Lithraeus atronotatus Pic (in 1960). Results were disappointing because $C$. infuscata did not become established and the other two insect species, although established, have had a negligible effect on the weed population (14). Systematic searches for pathogens (especially fungi) to be used as biocontrol agents for BP were initiated only in the last decade. Existing records of fungal pathogens associated with BP in Brazil were limited to a single taxon: Meliola rhois var. fexuosiseta (Speg.) Hansf. $(8,22)$. During the initial stages of the surveys (limited to the states of Rio de Janeiro and São Paulo) in 2001 to 2002, 11 new records of fungal diseases of BP were made (7). Three of the fungi caused black mildew (14), one of which was a newly

Corresponding author: R.W. Barreto, E-mail: rbarreto@ufv.br

Accepted for publication 24 October 2012.

http://dx.doi.org/10.1094/PDIS-06-12-0598-RE

(C) 2013 The American Phytopathological Society described species (Irenopsis schini-terebenthifolii D.M. Macedo \& R.W. Barreto). As acknowledged in the publication on black mildews on BP (20), such fungi are of no relevance for weed biocontrol because they cause limited damage to their hosts, and the publication of these results was aimed only at contributing to the knowledge of the mycobiota of BP. Among the other fungi collected on BP, Faria et al. (7) regarded an undescribed species of Septoria as the most promising biocontrol agent. Unfortunately, preliminary studies on the specificity of this species carried out at the University of Florida in 2008 revealed that, under controlled conditions, it was able to infect an endangered native Anacardiaceae, Rhus michauxii Sarg., thus, undermining the possibility of its introduction (J. Cuda, personal communication). There are still doubts as to whether such results represent a laboratory aberration (e.g., a false positive) or indicate a real threat to $R$. michauxii. Surveys in Brazil, covering a broader area than that of the initial surveys, were undertaken between 2008 and 2009 in the southern and southeastern states (Minas Gerais, Paraná, Rio de Janeiro, Santa Catarina, and São Paulo). Additionally, other ad hoc collections of diseased BP were made in recent years, including in the state of Espírito Santo (southeastern Brazil). Among the fungi collected in Espírito Santo, one was associated with severe blight symptoms. This article deals with the isolation, identification, and evaluation of the host range of this fungus.

\section{Materials and Methods}

Survey and specimen collection. During a survey in the coastal region of Espírito Santo, an isolated tree of BP bearing leaf spots which progressed to a general blight was observed at one locality, in the municipality of Guarapari, Meaipe. Samples were collected, dried in a plant press, and brought to the laboratory for further study. A representative specimen was deposited in the local herbarium at the Universidade Federal de Viçosa (VIC).

Morphological analysis. Diseased leaves were examined under a dissecting microscope and fungal structures were scraped from the leaves with a scalpel, mounted in lactofuchin, and observed under a microscope (BX 51; Olympus). A digital camera (E-volt e-330; Olympus) was attached to the microscope and used for image preparation. 
Culture description and deposit. Pure cultures were obtained by transferring spores from infected leaves onto vegetable brothagar (VBA; 27) with a sterile, fine-pointed needle. One culture was selected and deposited in the University culture collection, Coleção Octávio de Almeida Drumond (COAD). The fungus was subcultured on $90-\mathrm{mm}$ petri plates containing each of the following culture media: VBA, potato dextrose agar (PDA), and $2 \%$ malt extract-agar (MEA). These were then incubated at $25 \pm 2{ }^{\circ} \mathrm{C}$ either in the dark or under a 12 -h regime, with light provided by a set of two daylight 20-W fluorescent lamps (General Electric) and one 15-W black light blue lamp (Gran Light). The morphology and color of colonies were recorded after 1 week of growth. Colony color was described according to Rayner (30).

Molecular studies. The total genomic DNA of isolate COAD 1110 was extracted from mycelium scraped from a 7-day-old culture on PDA using the hexadecyl trimethyl-ammonium bromide method (23). The internal transcribed spacer (ITS) region was PCR amplified using the primers ITS-1 (5'TCCGTAGGTGAA CCTGCGG3') and ITS4 (5'TCCTCCGCTTATTGATATGC3') (36). The PCR fragments were purified and the nucleotide sequence was determined by means of the cyclic method of termination reaction with the Terminator Cycle Sequencing BigDye Kits (Applied Biosystems), with the same primers used in the amplification of the DNA 1000 MegaBACE Sequencing System. The sequence obtained from the observed species was compared using the BLAST protocol, with the sequences of related fungi deposited in GenBank (http://blast.ncbi.nlm.nih.gov/). The ITS sequence obtained for the isolate was deposited in GenBank.

Host-range test. The pathogenicity of the fungus was screened against a series of test-plants as well as to BP. Inoculum consisted of a suspension of conidia. Conidia were produced as follows: the isolate (COAD 1110) was grown on 90-mm-diameter plates containing VBA for 1 week at $25 \pm 2{ }^{\circ} \mathrm{C}$ under a light regime as described above. After this period, five 7-mm-diameter disks were taken from the periphery of the culture and used to seed $150 \mathrm{ml}$ of sterile liquid potato-carrot medium (200 g of potato $+200 \mathrm{~g}$ of carrot/liter of water) in 250-ml flasks stoppered with cotton plugs. The flasks were placed on an orbital agitator (MA 420; Marconi) adjusted to $150 \mathrm{rpm}$, at room temperature and light conditions, and left for 4 days. The resulting mycelial mass was then aseptically ground and blended with a homogenizer (MA102; Marconi) within the remaining medium, and an aliquot of $150 \mathrm{ml}$ was used to seed each of four previously autoclaved bags $\left(1 \mathrm{~h}\right.$ at $120^{\circ} \mathrm{C}[1$ Kilogram-force $\left.(\mathrm{Kgf}) / \mathrm{cm}^{2}\right]$ ) containing $75 \mathrm{ml}$ of water and $150 \mathrm{~g}$ of polished rice each. Four days later, each plastic bag was opened in order to allow gas exchange. By the eighth day, colonization of the substrate by the fungus was well advanced and the contents of each plastic bag were transferred to a plastic beaker containing 250 $\mathrm{ml}$ of $0.05 \%$ Tween 20 in sterile distilled water and thoroughly agitated with a glass rod. The first filtrate that was obtained was discarded because the spore yield was negligible. The colonized rice was then transferred to four aluminum trays ( 19 by 28 by 2 $\mathrm{cm})$ that were left uncovered in a growth room for 2 days at room temperature $\left(25 \pm 2^{\circ} \mathrm{C}\right)$ and an approximately 12-h light regime (light source as described above for culture descriptions, placed 40 $\mathrm{cm}$ above the bags). The colonized rice was transferred to a plastic beaker, as described above, the suspension was filtered through a layer of cheese cloth, and the resulting conidial suspension was adjusted to $1 \times 10^{5}$ conidia/ml with the aid of a haemocytometer. The suspension was then sprayed until run-off with a hand-held electric atomizer (P-600 plus; Multi-Hobby)onto three healthy individual test plants of each species (young plants less than 1 year of age and up to $30 \mathrm{~cm}$ in height, cultivated in 1.0-lirwe pots filled with a mixture of $1 / 3$ soil, $1 / 3$ sand, and $1 / 3$ manure). Each pot containing an individual treated plant was then wrapped with a plastic bag, cotton wool soaked in water was placed inside the bag at the base of each plant, and each pot was left with the base immersed in water in a plastic tray. This served as a humid chamber. The group of plants (inoculated and noninoculated) was left on a greenhouse bench for $48 \mathrm{~h}$ at $25 \pm 3^{\circ} \mathrm{C}$. Subsequently, the plastic bag was removed and the plants were kept on a bench in the greenhouse for the entire duration of the experiment. Plants were watered twice a day. Inoculated plants were observed daily for the appearance of disease symptoms for 1 month. Plant organs showing lesions on any of the inoculated individuals after 10 days were removed for closer examination under a dissecting microscope (SZX 7; Olympus), and five fragments were taken from those diseased plant parts and surface sterilized by immersion in $2 \%$ sodium hypochlorite for $3 \mathrm{~min}$, washed in sterile distilled water, and plated onto PDA plates. One healthy plant of each species sprayed with sterile tap water served as control. The hostrange test involved 24 plant species (Table 1) following a centrifugal-phylogenetic scheme (35). Some species were selected because they are known hosts of Corynespora cassiicola (Berk. \& M.A. Curtis) C.T. Wei (Table 1) (8). The host-range test was repeated.

\section{Results}

Survey and specimen collection. A single fungal species was consistently associated with disease symptoms on the specimen of BP collected from Meaípe, and this was subsequently isolated in pure culture.

Morphological analysis. Fungal morphology was recognized as typical for $C$. cassiicola as described in the mycological literature (6).

Molecular studies. The comparison made between the sequence obtained for the fungus from $\mathrm{BP}$ and numerous from $C$. cassiicola deposited in GenBank for the same regions (e.g., AY238605, AY238606, FJ852704, and FJ852706) through a BLAST search yielded a $99 \%$ sequence homology.

The combination of the results obtained for the morphological and molecular analyses, and host-range restriction to BP, indicates that the fungus on BP represents a new forma specialis of C. cassiicola. This is described below:

Corynespora cassiicola (Berk. \& M.A. Curtis) C.T. Wei f. sp. schinii (Fig. 1)

GenBank: JX893520

Lesions on leaves initially black, punctiform circular to elliptical becoming irregular with age, slightly collapsed centrally, 1.5-2.5 $\times$ $1.0-4.5 \mathrm{~mm}$ diameter, coalescing and leading to foliage blight and defoliation; in artificial inoculation of young plants, necrotic lesions also appearing on petioles, branches and stems as dark

Table 1. List of plant species included in the host range evaluation of Corynespora cassiicola f. sp. schinii

\begin{tabular}{|c|c|}
\hline Family & Species \\
\hline Anacardiaceae & $\begin{array}{l}\text { Anacardium occidentale } \mathrm{L} \text {. } \\
\text { Mangifera indica } \mathrm{L} \text {. } \\
\text { Myracrodruon urundeuva Allemão } \\
\text { Pistacia vera } \mathrm{L} . \\
\text { Rhus aromatica Aiton } \\
\text { Rhus copallinum } \mathrm{L} . \\
\text { Spondias cythera Tussac } \\
\text { Spondias mombin } \mathrm{L} \text {. } \\
\text { Spondias purpurea } \mathrm{L} \text {. } \\
\text { Schinus molle } \mathrm{L} \text {. } \\
\text { Schinus terebinthifolius Radd. (Florida source) } \\
\text { Schinus terebinthifolius } \text { Radd. (Hawai'i source) }\end{array}$ \\
\hline Caricaceae & Carica papaya $\mathrm{L}$. \\
\hline Cucurbitaceae & Cucumis sativus $\mathrm{L}$. \\
\hline Euphorbiaceae & $\begin{array}{l}\text { Hevea brasiliensis (Willd. ex A. Juss.) Müll. Arg. } \\
\text { Ricinus communis L. }\end{array}$ \\
\hline Fabaceae & Glycine $\max$ (L.) Merr. \\
\hline Meliaceae & $\begin{array}{l}\text { Azadirachta indica (L.) Adelb. } \\
\text { Cedrela odorata } \mathrm{L} \text {. }\end{array}$ \\
\hline Myrtaceae & Eucalyptus grandis W. Hill ex Maiden \\
\hline Rutaceae & $\begin{array}{l}\text { Citrus deliciosa Ten. } \\
\text { Citrus limonia Osbeck }\end{array}$ \\
\hline Solanaceae & $\begin{array}{l}\text { Nicotiana tabacum } \mathrm{L} . \\
\text { Solanum lycopersicum } \mathrm{L} \text {. } \\
\text { Solanum melongena } \mathrm{L} .\end{array}$ \\
\hline
\end{tabular}


sunken necrotic stripes and leading to die-back. Conidiophores solitary, straight, cylindrical, 325-1175 $\times 5-7 \mu \mathrm{m}$, unbranched, 518 septate, dark brown, smooth. Conidiogenous cells terminal integrated, holoblastic with per current proliferations, cylindrical, 20-12 $\times 5-8 \mu \mathrm{m}$, pale brown, smooth. Conidiogenous loci flat, 3-5 $\mu \mathrm{m}$, darkened and thickened. Conidia holoblastic in acropetal chains, obovoid, fusiform to subcylindrical, $60-210 \times 3-8 \mu \mathrm{m}$, base truncate, apex rounded, 2-15 septate, hilum thickened, darkened, pale brown, smooth.

In culture: relatively slow growing (9-cm-diameter in 13 days), cottony or powdery centrally, either raised or flattened centrally, pale olive gray, pale mouse gray or pale gray, subtly pigmenting the medium with amber diffusate in PDA; periphery of white immersed dendritic mycelium in VBA and entirely immersed and dendritic in MEA; reverse bluish gray to greenish-black or dark brown centrally, with greenish-brown periphery; sporulation sparse.

Material examined: BRAZIL, Espirito Santo, municipality of Guaraparí, Meaípe (Praia de Bacutia), on Schinus terebinthifolius, 25 Feb 2008, O. L. Pereira (VIC 30789; COAD 1110).

Host-range test. BP was the only species that developed disease symptoms after inoculation with the fungus. Two days after inoculation, plants of both accessions (Hawai'i and Florida) had developed numerous necrotic spots on leaves and some leaf drop had started (Fig. 2), suggesting the presence of phytotoxic compounds as found for C. cassiicola f. sp. lantanae (25). C. cassiicola was the only fungus found sporulating on necrotic tissues of BP and was also isolated in pure culture from infected leaves, petioles, and stems. No other plant species included in the host range test showed any symptoms during the 1-month post-inoculation observations in the two rounds of inoculation. Three months after the

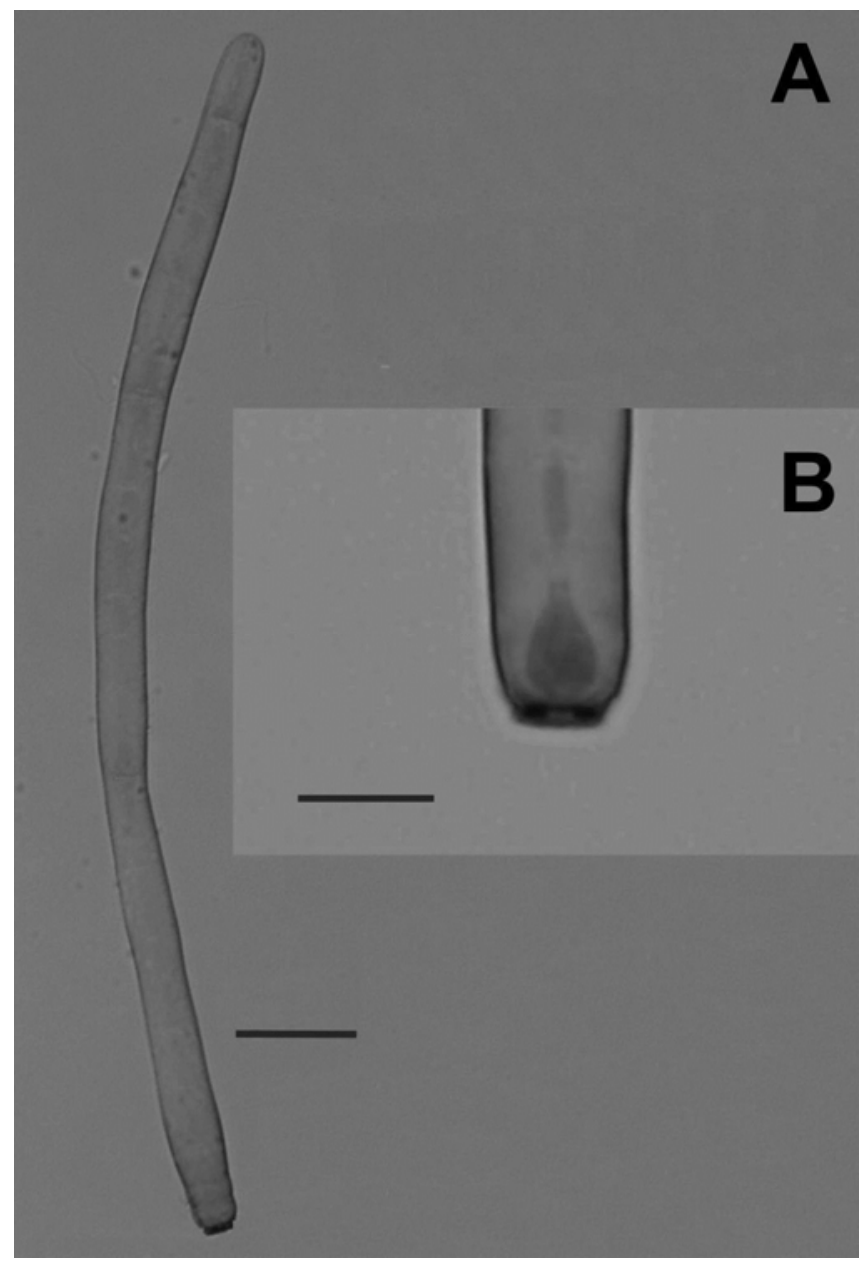

Fig. 1. A, Conidium of Corynespora cassiicola (bar $=20 \mu \mathrm{m}$ ). B, Close-up of the truncated, thickened, and darkened hilum (bar $=10 \mu \mathrm{m})$. experiment was terminated, it was observed that all BP individuals inoculated in the host-range test and left in the greenhouse were killed by the disease.

\section{Discussion}

Although the fungus isolated from BP was found to have conidia with a diameter that was $3.0 \mu \mathrm{m}$ wider than that given in published descriptions of $C$. cassiicola (3), the size difference is not a sufficient basis to consider this fungal isolate as a separate species of Corynespora. The genomic region which has been most investigated for Corynespora spp. is the ITS and the most commonly used primers for the identification of $C$. cassiicola are ITS1 and ITS4 $(27,32)$. Results from studies that compared isolates of $C$. cassiicola obtained from bean, eggplant, rubber, cucumber, papaya, tomato, sesame, and cowpea based on morphological features, ribosomal DNA ITS region sequence, and inter-simplesequence repeat data have been published recently (28). In these studies, the authors found considerable variability among the morphological features of the isolates; however, they also found that, using the basic local alignment search tool, a high similarity (99 to $100 \%$ ) existed between their own sequences and those of C. cassiicola isolates already deposited in GenBank. C. cassiicola is regarded as a species complex and there is ongoing work aimed at unraveling its phylogeny that may better resolve its status in the future. In the case of the isolate from BP, although morphologically indistinct from other isolates of $C$. cassiicola and phylogenetically fitting within this taxon, results of the host-range evaluation allows for the recognition of the new forma specialis, which is proposed here.

C. cassiicola has been isolated from a range of substrates and is known to be able to exploit other niches besides that of a plant pathogen. It has also been reported as an endophyte, a saprophyte $(2,10,13,15,17,19,26,34)$ and it has also been reported as a mycoparasite (31). C. cassiicola is widely regarded as a nonspecific pathogen and has been associated with more than 300 hosts (8). Such a broad host-range-pathogenic fungus as $C$. cassiicola would appear, at first, to be an inappropriate choice for use as a weed biocontrol agent, because it might represent a threat to cultivated and native plants in the target areas. Nevertheless, regarding $C$. cassiicola a nonspecific pathogen is now viewed as incorrect. As pointed out by Smith (33), "the generalization that individual $C$. cassiicola isolates have a wide host range is not supported by the literature because host specific isolates, isolates pathogenic to select hosts, and weak pathogens or secondary invaders of senescent tissue are known to exist" $(3,15,24,25)$. Indeed, there is evidence that $C$. cassiicola represents a complex of forms that vary from having a broad host-range (4) to being host specific $(4,5)$. For example, one isolate has been studied as a biocontrol agent for the major pan-tropical weed, Lantana camara L. This was collected from its native range in Brazil (state of Paraná) and shown to be highly host specific and only able to infect certain populations within L. camara (25). The fungus was then described as a novel forma specialis of $C$. cassiicola $(C$. cassiicola $\mathrm{f}$. sp. lantanae) and considered safe for use either in classical biocontrol or as a mycoherbicide (25). Based on the vast number of weeds that serve as hosts to C. cassiicola and past demonstration of host specificity in some isolates, there is great potential for the discovery of additional isolates useful for biological control (33). Other authors have also proposed the recognition of formae speciales for other hostspecific populations of this fungus $(22,24,33)$.

Only two species of Anacardiaceae have been reported as hosts of $C$. cassiicola: Spondias purpurea L. (9) and Mangifera indica L. $(5,22)$. There is one obscure report of the occurrence of a Corynespora sp. on BP. This is limited to a citation of the fungus in a list of plant diseases in Florida, without any complementary detail (1).The present publication provides the first confirmed report of C. cassiicola on BP. Results of the host-range test performed in this study have indicated that the isolate from BP is highly host specific and safe for use as a biocontrol agent against BP in exotic situations such as in Florida and Hawai'i. However, before ap- 
proval for field release can be petitioned, native North American and Hawaiian Anacardiaceae spp. will need to be tested.

Additionally, because $C$. cassiicola f. sp. schinii can easily be mass-produced, there is the potential of using this fungus in an augmentative (mycoherbicide) approach or in combination with other biocontrol agents, such as insects, for the integrated management of BP.

\section{Acknowledgments}

This study forms part of a Ph.D. thesis presented by D. M. Macedo to the Departamento de Fitopatologia/Universidade Federal de Viçosa, undertaken with financial support from the Fundação de Amparo à Pesquisa do Estado de Minas Gerais (FAPEMIG), Florida Department of Environmental Protection, Florida Fish and Wildlife Conservation Commission, South Florida Water Management
District, United States Department of Agriculture-Agricultural Research Service, and the Conselho Nacional do Desenvolvimento Científico e Tecnológico (CNPq).

\section{Literature Cited}

1. Alfieri, S. A., Jr., Langdon, K. R., Wehlburg, C., and Kimbrough, J. W. 1984. Index of plant diseases in Florida (revised). Fla. Dep. Agric. Consumer Serv. Div. Plant Ind. Bull. 11:1-389.

2. Collado. J., Platas, G., Gonzalez, I., and Pelaez, F. 1999. Geographical and seasonal influences on the distribution of fungal endophytes in Quercus ilex. New Phytol. 144:525-532.

3. Cutrim, F. A., and Silva, G. S. 2003. Pathogenicity of Corynespora cassiicola to different plant species. Fitopatol. Bras. 28:193-194.

4. de Lima, M. R. F., Souza, L. J., dos Santos, A. F., de Andrade, M. C. C., Sant'Ana, A. E. G., Genet, J. P., Marquez, B., Neuville, L., and Moreau, N.
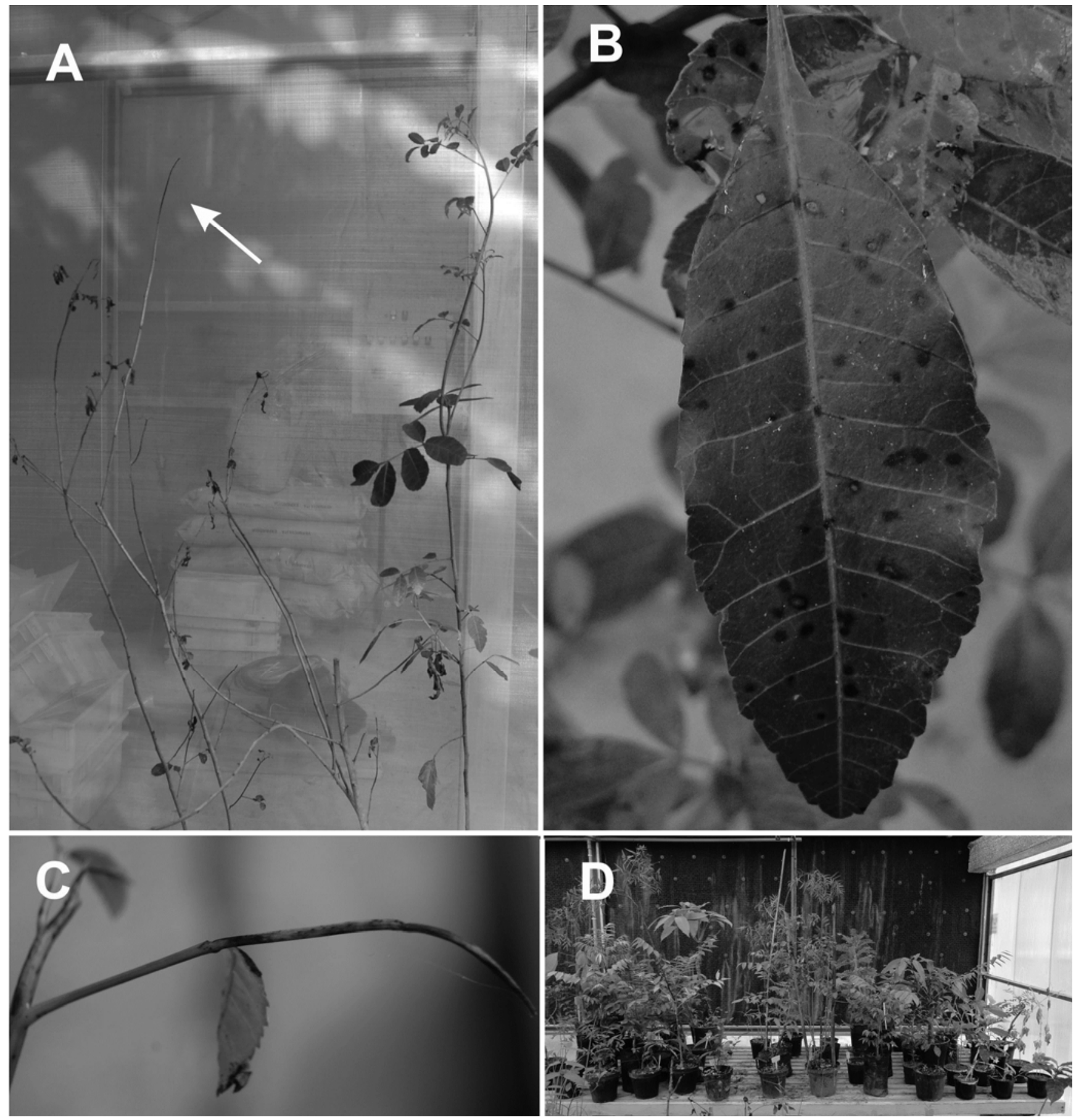

Fig. 2. A, Plants of Schinus terebinthifolius inoculated with Corynespora cassiicola f. sp. schinii (three branches on the left) and one control plant, not inoculated (right); white arrow indicates dieback of a branch (note complete loss of leaves) 1 week after inoculation. B, Leaf spotting resulting from inoculation of $S$. terebinthifolius (Florida source) with C. cassiicola f. sp. schinii (2 days after inoculation). C, Close-up of a S. terebinthifolius (Hawaiian source) stem infected with C. cassiicola f. sp. schinii and with dieback. D, Group of test plants inoculated with C. cassiicola f. sp. schinii. 
2006. Anti-bacterial activity of some Brazilian medicinal plants. J Ethnopharmacol. 105:137-147.

5. Dixon, L. J., Schlub, R. L., Pernezny, K., and Datnoff, L. E. 2009. Host specialization and phylogenetic diversity of Corynespora cassiicola. Phytopathology 99:1015-1027.

6. Ellis, M. B., and Holliday, P. 1971.Corynespora cassiicola. CMI Descriptions of Pathogenic Fungi and Bacteria 303:1-2.

7. Faria, A. B. V., Barreto, R. W., and Cuda, J. 2008. Fungal pathogens of Schinus terebinthifolius from Brazil as potential biocontrol agents. Pages 270-277 in: Proc. XII Int. Symp. Biol. Control Weeds M. H. Julien, R. Sforza, M. C. Bon, H. C. Evans, P. E. Hatcher, H. L. Hinz, and B. G. Rector, eds. CAB International, Wallingford, UK.

8. Farr, D. F., and Rossman, A. Y. 2012. Fungal Databases. Systematic Mycology and Microbiology Laboratory, ARS, USDA. http://nt.ars-grin.gov/ fungaldatabases/

9. FLEPPC Plant List Committee. 2009. Florida Exotic Pest Plant Council's 2009 List of Invasive Species. www.fleppc.org

10. Gond, S. K., Verma, V. C., Kumar, A., Kumar, V., and Kharwar, R. N. 2007. Study of endophytic fungal community from different parts of Aegle marmelos Correae (Rutaceae) from Varanasi (India). World J. Microbiol. Biotechnol. 23:1371-1375.

11. Hawaii State Alien Species Coordinator (HSASC). 2012. http://www. state.hi.us

12. Hayes, L., and Paynter, Q. 2009. Deciding which weeds to target for biocontrol. What's new in biological control of weeds? Manaaki Whenua Landcare Res. 48:5-7.

13. Hyde, K. D., McKenzie, E. H. C., and Dalisay, T. U. 2001. Saprobic fungi on bamboo culms. Fungal Divers. 7:35-48

14. Juliens, M. H., and Griffthis, M. W. 1998. Biological Control of Weeds: A World Catalogue of Agents and Their Target Weeds, 4th ed. CAB International, Wallingford, UK.

15. Kingsland, G. C. 1985. Pathogenicity and epidemiology of Corynespora cassiicola in the Republic of the Seychelles. Acta Hortic. 153:229-230.

16. Krauss, N. L. 1963. Biological control investigations on Christmas berry (Schinus terebinthifolius) and Emex (Emex spp.). Proc. Hawaiian Entomol. Soc. 18:281-287.

17. Lee, S., Melnik, V., Taylor, J. E., and Crous. P. W. 2004. Diversity of saprobic hyphomycetes on Proteaceae and Restionaceae from South Africa. Fungal Divers. 17:91-114.

18. Lorenzi, H., and Souza, H. M. 1992. Árvores do Brasil. Editora Plantarum, Nova Odessa, São Paulo, Brazil

19. Lumyong, P., Photita, W., McKenzie, E. H. C., Hyde, K. D., and Lumyong, S. 2003. Saprobic fungi on dead wild banana. Mycotaxon 85:345-346.

20. Macedo, D. M., Pinho, D. B., Barreto, R. W., Pereira, O. L., and Cuda, J. P. 2010. Black mildew fungi (Meliolaceae) associated with Schinus terebinthifolius (Brazilian pepper tree) in Brazil. Mycotaxon 114:429437

21. Martinez, M. J., Betancourt, J., Alonso-Gonzalez, N., and Jauregui, A. 1996. Screening of some Cuban medicinal plants for antimicrobial activity. J. Ethnopharmacol. 52:171-174.
22. Mendes, M. A. S., and Urben, A. F. 2012. Fungos relatados em plantas no Brasil, Laboratório de Quarentena Vegetal. Embrapa Recursos Genéticos e Biotecnologia, Brasília, DF. http://pragawall.cenargen.embrapa.br/aiq web/michtml/fgbanco01.asp

23. Murray, M. G., and Thompson, W. F. 1980 Rapid isolation of high molecular weight DNA. Nucleic Acids Res. 8:4321-4325.

24. Onesirosan, P. T., Arny, D. C., and Durbin, R. D. 1974. Host specificity of Nigerian and North American isolates of Corynespora cassiicola. Phytopathology 64:1364-1367.

25. Pereira, J. M., Barreto, R. W., Ellison, C. A., and Maffia, L. A. 2003. Corynespora cassiicola f. sp. lantanae: a potential biocontrol agent from Brazil for Lantana camara. Biol. Control 26:21-31.

26. Promputtha, I., Lumyong, A., Dhanasekaran, V., McKenzie, E. H. C., Hyde, K. D., and Jeewon, R. 2007. A phylogenetic evaluation of whether endophytes become saprotrophs at host senescence. Microbiol. Ecol. 53:579590.

27. Qi, Y., Xie, Y., Zhang, X., Pu, J., Zhang, H., Huang, S., and Zhang, H. 2009 Molecular and pathologic variation identified among isolates of Corynespora cassiicola. Mol. Biotechnol. 41:145-151.

28. Qi, Y., Zhang, X., Pu, J., Liu, X., Lu, Y., Zhang, H., Zhang, H., Lv, Y., and Xie, Y. 2011. Morphological and molecular analysis of genetic variability within isolates of Corynespora cassiicola from different hosts. Eur. J. Plan Pathol. 130:83-95.

29. Randall, J. M. 2000. Schinus terebinthifolius Raddi, Pages 282-287 in: Invasive Plants of California's Wildlands. C. C. Bossard and J. M. M. C. Hoshovsky, eds. University of California Press, Berkeley, CA

30. Rayner, R. W. 1970. A Mycological Colour Chart. Commonwealth Mycological Institute and British Mycological Society, Kew, Surrey, UK

31. Seixas, C. D. S. Controle biológico de Miconia calvescens DC (Melastomataceae) com fitopatógenos. Ph.D. dissertation, Universidade Federal de Viçosa, Brazil.

32. Silva, W. P. K, Deverall, B. J., and Lyon, B. R. 1998. Molecular, physiological and pathological characterization of Corynespora leaf spot fungi from rubber plantations in Sri Lanka. Plant Pathol. 47:267-277.

33. Smith, L. J. 2008. Host range, phylogenetic, and pathogenic diversity of Corynespora cassiicola (Berk. \& Curt.) Wei. Ph.D. dissertation, University of Florida, Gainesville.

34. Suryanarayanan, T. S., Murali, T. S., and Venkatesan, G. 2002. Occurrence and distribution of fungal endophytes in tropical forests across a rainfall gradient. Can. J. Bot. 80:818-826.

35. Wapshere, A. J. 1974. A strategy for evaluation of the safety of organisms for biological weed control. Ann. Appl. Biol. 77:201-211.

36. White, T. J., Bruns, T., Lee, S., and Taylor, J. W. 1990. Amplification and direct sequencing of fungal ribosomal RNA genes for phylogenetics. Pages 55-84 in: PCR Protocols: A Guide to Methods and Applications. M. A. In nis, D. H. Gelfand, J. J. Sninsky, and T. J. White, eds. Academic Press, Inc., New York.

37. Williams, D. A., Muchugu, E., Overholt, W. A., and Cuda, J. P. 2007. Colonization patterns of the invasive Brazilian peppertree, Schinus terebinthifolius, in Florida. Heredity 98:284-293. 